\title{
Symbol formation
}

\author{
Cornelius Steckner \\ Etruskerstr. 22, D 50996 Köln, Germany \\ e-mail: focas@nexgo.de
}

\begin{abstract}
Symbol formation is a term used to unify the view on the interdependencies in the research of the Hamburg University before 1933: the Philosophical Institute (William Stern, Ernst Cassirer), the Psychological Institute (Stern) with its laboratory (Heinz Werner) in cooperation with the later joining Umwelt Institut (Jakob von Uexküll). The term, definitely used by Cassirer and Werner, is associated with the personalistic approach: "Keine Gestalt ohne Gestalter" (Stern), but also covers related terms like "melody of motion" (Uexküll), and "relational content" (Cassirer), discussing the term "empirical scheme" (Kant). All this scientific interest addressed personal forces to structure thresholds in equivalent stimuli. This view on intermodal formation allowed research in common aspects in the environments of animals, of children and adults to meet there the symbol formation of artists (Weimar Bauhaus) and poets like R. M. Rilke, a friend of Uexküll.
\end{abstract}

\section{Motion and emotion}

"'Movement in response to an optical impression,' says Jakob von Uexküll, 'is an integrating factor in the melody of the environment, by means of which the forms of objects are brought to inner realisation"" (Werner 1948: 67). With reference to Uexküll, Heinz Werner (18901964) in his Comparative Psychology of Mental Development outlines the formative motor processes of realisation:

The high degree of unity between subject and object mediated by the motoraffective reactivity of the organism results in a dynamic, rather than static, apprehension of things. Things as constituent elements of a dynamic event must necessarily be dynamic in nature. (Werner 1948: 67) 
Anticipatory tonal forces ${ }^{1}$ behind the dynamic interrelation of motion and emotion formed both the environmental and internal worlds. Changing thresholds of equivalent stimuli shaped the dynamic interrelations in the things-of-action and their signal-qualities. The interrelation could be varied dynamically by experimental attitude change from "Sachlichkeit" to "Leiblichkeit" (Stern 1950: 156; Wohlwill 1930: 39). Far from distanced object perception, then a zig-zag of lines could become an equivalent stimulus to match the emotional content of a metal quality (Werner 1948: fig. 12), and a specific motion could match a tone or colour. This was the language of abstract expressionism in the arts. The emotional equivalence in expression and perception, explored by Heinz Werner in the Hamburg Psychological Laboratory until 1933, was called "physiognomic perception" (Werner 1926: 45), while William Stern (1871-1938), head of the Hamburg Psychological Institute (Psychologisches Seminar; Stern 1931) used the term "Synkinesie" to label expressive motor activity (Stern 1950: 218). Furthermore Stern focused what he called vicarious functioning (Stern 1950: 219; Werner 1945: 317). What on one hand looked like synesthetic (Stern 1950: 215), on the other hand allowed the blind to read a word by touch.

Finished in 1934, Sterns Allgemeine Psychologie auf personalistischer Grundlage reflected the collaborate scientific aims at the former "Hamburgische Universität" 1919-1933. The more this became visible in the second edition (Stern 1950). Ernst Cassirer (18741945), together with Stern, there had been head of the Hamburg Philosophical Institute (Philosophisches Seminar), while the Psychological Institute of Stern had Heinz Werner as the head of its psychological laboratory (Psychologisches Laboratorium). This research focused the biology of the person, distinguishing in contact with Jakob von Uexküll and his Hamburg Umwelt Institute (Institut für Umweltforschung) biological and transbiological aspects (Stern 1950: 35). This also is preserved in Cassirer's Philosophie der symbolischen Formen (1990 [1929]) and the later editions of Werner's Comparative Psychology of Mental Development (1940).

The related research focused organic symbol formation to act across the environment. Symbol formation was seen an inter-indivi-

Symbol formation (Werner and Kaplan 1963) also is known as the "Tonustheorie der Wahrnehmung": perceptual neurogenic muscle tonus modulation meets environmental forces. These are neuronal mechanisms in behavioral aspects of sensation. 
dual functional circle and personal binding process, driven by the dynamics of motivation, motion and emotion. Cassirer, like Uexküll, distinguished action-space and symbol-space (Cassirer 1994: 179), while Werner spoke of "things-of-action" and of "signal-things" (Werner 1948: 59). The man-animal interrelation in the related crossworld symbol formation was focused in collaboration with Uexküll's Hamburg Umwelt Institut, the exploration of the environments of children, embedded in the environment of the adult, was focused by Martha Muchow (1892-1933). She was the assistant of William Stern, who himself pronounced the personal characteristics in symbol formation in his "critical personalistics" (Werner 1938). Accordingly Cassirer focused the relational binding in communicative and explorative symbol formation in his "theory of symbol formation", while Werner looked at the dynamics of symbol formation in culture (Werner 1948; Werner, Kaplan 1963), which brought him together with art and art education. This guided Werner to understand motor tonality in the formative forces of modern art and its motivating interrelation with the environment: "De même, l'osieau au fond de l'azur représente d'abord l'immortelle envie de planer au dessus des choses humaines, mais déjà vous êtes l'oiseau lui-même" (Charles Baudelaire, Les paradis artificiels, 1860; Werner 1958: 56; but not 1948: 82). The interest in the formation of the artist's worlds Uexküll joined with the poet Rainer Maria Rilke. Though, there was an empirical basis of these interests.

\section{Threshold in equivalent stimuli}

In 1948, when the second revised edition of his "tonal theory of perception" was published, Heinz Werner had become professor of psychology at Clark University, Worcester, MA, still recalling several former experiments at the Hamburg Psychological Laboratory, which had been closed in 1933. Until then the Hamburg Psychological Institute shared many experiments with the Umwelt Institut (Werner 1948: 65, 115). Many terms and concepts Werner had to transform to communicate the ideas of the Hamburg organic approach to his new audience. The catching realisation (be-merken) now was described as a signal-property (Merkzeichen) to drive (be-wirken) of things-ofaction (Wirkzeichen), performing equivalent stimuli for the tonality of the related receptors and effectors. This were the terms Heinz Werner used to describe the functional circle forming an environment by 
perception and action. The new audience learned more about the related collaboration of the Hamburg institutes: "one of the most promising experiments inquiring into a world built up of things-ofaction and signal-qualities has been carried out by E. G. Sarris in Uexküll's 'Umwelt Institut' in cooperation with our Hamburg Psychological Laboratory" (Werner 1948: 61). These equivalent stimuli then were used to explore the dog's environment, to understand the action related communication of dog and man across their different biological environments. William Stern as the head of the Hamburg Psychological Institute intended to communicate the Hamburg biological approach to his colleagues and invited Uexküll to talk in April 1931 to the Hamburg Congress of Psychology about "Das Duftfeld des Hundes". This speech and the following discussion was a critical point for the political acceptance of the biological view of the Hamburg Institutes (G. v. Uexküll 1964: 168). Nevertheless, the methodical background of the biological approach Uexküll brought to the audience. In short he described the motivation to focus the threshold in equivalent stimuli, directly addressing the joined research of his Umwelt Institut with the psychological laboratory of the Hamburg University:

Die Umweltlehre sucht die Schwierigkeit, die die Unerkennbarkeit der Empfindung tierischer Subjekte der Forschung bietet, dadurch auszugleichen, daß sie nach Merkmalen sucht, auf die die Subjekte reagieren. [...] Die Umweltforschung vermeidet die unkontrollierbaren Analogieschlüsse aus der menschlichen Psyche auf die Tierseele, indem sie nicht die Empfindungen und Gefühle der Tiere untersucht, sondern ihre Objektivationen in der Umwelt. Sie faßt alle Objekte als Merkmalträger des Tiersubjektes auf. Ist in der 'Umgebung' des Tieres ein roter, eckiger Gegenstand gegeben, der dem Tiersubjekt als Reizspender dient, so fragt sie, ob die Form oder die Farbe, oder beide in der 'Umwelt' des Tieres zu Merkmalen werden, und kümmert sich nicht darum, welcher Art die Empfindungen sind, die dabei im Tiere wachgerufen werden. Statt der Empfindungen erforscht sie die Eigenarten der speziellen Tierdinge in der Welt des gegebenen Subjektes. [...] Sie berücksichtigt dabei seinen momentanen Schwellenwert, denn der gleiche Gegenstand kann bald eine Hauptrolle auf der Umweltbühne des Subjektes spielen, bald völlig in der Versenkung verschwinden. (Uexküll 1932: 432)

Werner presented his recent research in sensation (Werner 1932: 190), and the discussion touched the related research by Wolfgang Metzger and Erich Moritz von Hornbostel. In 1931 Karlfried von Dürckheim (Leipzig) had presented his related studies in personal space to the Hamburg Congress (Dürckheim 1932: 318), in 1933 he pronounced 
his ideas about personal time (Dürckheim 1934: 129), while Stern presented his paper "Raum und Zeit als personale Dimensionen" (Stern 1933) to this last free conference. Both these conferences of 1931 and 1933 had unveiled not just an interrelation, but a common basis in the organic approach.

\section{The common basis of the organic approach}

In 1931 a common methodical basis in the interest in the organic relation of the Umwelt and the Innenwelt of the subjects became visible, leading to the question of their common basis. Something common was in the signal-quality of a chair, inviting the tired to sit on, its "sitting-tone" for dog and man (Werner 1932: 61), and in the motor qualities of the acoustic tone, which not just exists as a perception coming then and there from the environment, but also as a signal arising and affecting the human bodies internal tonality in general. There were reasons, to use trumpets instead of harps, to signal the appropriate melody of movement.

Motor dynamics to cause object constancies over time, later Alfred Prinz Auersperg discussed with reference to Uexküll in 1937 (Auersperg 1937: 129), at a time, Stern already had left Europe.

The symbol formation, composing a communicative motor melody across time, Uexküll in his Theoretical Biology had illustrated by a movie sequence of a jumping ball. The piled slides of this sequence represent the signal qualities, the human organism needs to access, to perceive the given object constancy in space-time. This organic formation of a movement across time, Stern had discussed in 1894 in his article "Die Wahrnehmung von Bewegungen vermittelst des Auges" (Stern 1894), getting the key for his personalistic theory, to which Heinz Werner later introduced the readers of Character and Personality in 1938 (Werner 1938). In short, this was an introduction to the idea of the organic "personal world", generated and dependend on the characteristics of the individual: "... each individual has but one character emerging from the interaction of internally conditioned striving with the 'actionalizing' factors of the personal world. Expressed otherwise, character is both (and equally) 'intelligible' and 'empirical"' (Werner 1938: 122). The words used by Werner referred to terms used earlier by Kant, to describe an aspect also Uexküll had brought to debate in 1907. 


\section{Function and substance}

When Uexküll had published his "Umrisse einer kommenden Weltanschauung" in 1907, Constantin Gutberlet, the editor of the Philosophisches Jahrbuch in his article "Die Substanz als Bewegungsmelodie" (Gutberlet 1907) had picked out the critical point, where Uexküll had linked his term "Bewegungsmelodie" with the "empirische Schema der Gegenstände", an expression used by Kant in his "Kritik der reinen Vernunft" (2nd ed, 1787, book 2: "Von dem Schematismus der reinen Verstandesbegriffe"; Cassirer, Das Erkenntnisproblem, 2, 1922 [1907]: 716). Gutberlet rejected the Kantian position in general, just the moment Ernst Cassirer, later together with Stern head of the Hamburg Philosophical Institute, prepared his "Substanzbegriff und Funktionsbegriff: Untersuchungen über die Grundfragen der Erkenntniskritik" (Cassirer 1910). There Cassirer proposed a psychology of relations (Cassirer 1910: 433) to catch the "Relationsgehalt", binding the subject and the object to each other as complementary motor events: "wie zwei aufeinander bezogene und abgestimmte Bewegungsformen, die wir jedoch niemals rein und selbständig zu isolieren, sondern nur in ihrer wechselseitigen Bestimmung durch einander zu bestimmen vermögen" (Cassirer 1910: 435).

In the misinterpretation of this stream of consciousness, William James had detected "the psychologist's fallacy" (Cassirer 1910: 441). The relational content, the formation of structures in the dynamial interrelational processes became the focus of the future Hamburg philosopy and psychology (Werner 1922: 241) in cooperation with Uexküll. "Keine Gestalt ohne Gestalter", William Stern pronounced to express the specific Hamburg personalistic position, to address the communicational aspect of the "Relationsgehalt", which in 1910 took Cassirer from the mathematical subject of motion (Cassirer 1910: 158) and the numerical substance (Cassirer 1910: 206) to a theory of signs (Cassirer 1910: 402): "We do not realize objects, but we cognize objectively": “... wir erkennen gegenständlich, indem wir innerhalb des gleichförmigen Ablaufs der Erfahrungsinhalte bestimmte Abgrenzungen schaffen und bestimmte dauernde Elemente und Verknüpfungszusammenhänge fixieren". This functional binding (Cassirer 1910: 122) allows to catch and to communicate the relational scheme across space and time. 
The renewed idea of the scheme allowed to understand constancies in personal dynamical processes, which generated the substance of the object and made the sign:

In der Tat liegen unseren reinen sinnlichen Begriffen nicht Bilder der Gegenstände, sondern Schemata zugrunde... Der Begriff vom Hunde bedeutet eine Regel, nach welcher meine Einbildungskraft die Gestalt eines vierfüßigen Tieres allgemein verzeichnen kann, ohne auf irgendeine einzige besondere Gestalt, die mir die Erfahrung darbietet, oder auch ein jedes mögliche Bild, was ich in concreto darstellen kann, eingeschränkt zu sein. (I. Kant, Kritik der reinen Vernunft, 2nd ed., 1787, book 2)

Uexküll's Theoretical Biology has chapter on the scheme (Uexküll 1920: 36) has examples of the formation of motor melodies, to distinguish further thing and object, object and substance, and object and "Gegenstand", like a ladder, remaining meaningless unless the knowledge of its melody allows to serve motion. The personal performance producing and communicating these relational rules later made the motto of the Hamburg institutes: "Keine Gestalt ohne Gestalter!" The related personalistic chapters on interpersonal perception of space and time (Stern 1950: 206; 211) focus the same object constancies, as touched by Uexküll. In this personalism, in Werners "symbol formation" and in Cassirers philosophy of symbolic forms remain the outlines of the "psychology of relations", proposed by Cassirer in Substanzbegriff und Funktionsbegriff (Cassirer 1910: 433). To illustrate this, Cassirer there pointed to the relational binding of a melody across a variety of transpositions, leading from the author via the orchestra to the audience in the theatre. This "Tongestalt" across time, consequently lead Cassirer to the "Raumgestalt" across space (Cassirer 1910: 442). These relational compounds were the same, his Hamburg colleagues addressed as "compositions" or "melodies".

In this organic view, the object constancies formed by artists, all are manifestations of personal worlds. Equivalent stimuli Uexküll had in mind, when he shared his interest in the empirical scheme of objects with the poet Rainer Maria Rilke, when in 1905 they both discussed the idea of the scheme, as proposed by Kant in his "Kritik der reinen Vernunft". An edition of this book Uexküll once dedicated to Rilke, remaining still in the Rilke-Archive.

When Uexküll communicated his ideas to the public, the new Cassirer edition became the standard (Immanuel Kant, Werke, vol. 1-11, 
Berlin 1911-1921, ed. E. Cassirer). The term "melody of motion" for the empirical scheme of the objects became a perfect expression to serve Uexküll and Rilke. Gudrun v. Uexküll in her biography of Jakob v. Uexküll 1964 prints the facsimile of Rilke's poem "The Panther", handwritten by Rilke himself for Uexküll in April 1905. The rhythm of the words there represents by its rhythm the specific melody of motion (Bewegungsmelodie) of the panther in his cage. There are different translations of this poem, more or less keeping the rhythm of movement as a melody of recognition, which allows to realize the panther:

Sein Blick ist vom Vorübergehn der Stäbe so müd geworden, daß er nicht mehr fühlt; ihm ist, als ob es tausend Stäbe gäbe und hinter tausend Stäben keine Welt.

Though Gutberlet in 1907 had rejected the idea to bind recognition by melodies of motion, motor rhythm in 1900 definitely was in the focus of the sciences and the arts. Ernst Meumann in Hamburg surveyed in his Einführung in die Ästhetik der Gegenwart (3rd ed. 1919) the related research in the productive processes to generate and perceive works of arts. There he mentions research by H. Münsterberg and A. Pierce, by Ethel D. Puffer (Psychology of Beauty, 1905) and George Malcom Stratton (Psychology and Culture, 1903) to understand vision related spatial "rhythmical equivalents", research to be continued by William Stern and Heinz Werner as followers of Meumann. Without knowledge of these psychological experiments, in his 1907 article on the future biological world view, Uexküll also had addressed the melodies of the environment by the fact, that landscape painting is the representation of a specific melody to guide the recognition of the landscape itself. Quoting from Uexküll, to these melodies and the proposed psychology of relations also Heinz Werners Comparative Psychology of mental development refers. It is not that surprising, because the mental development itself for him is a structured spatiotemporal differentiation, a "geistiger Bauplan", a dynamical process to generate the "Gefüge der Gegenstände". Werner there is referencing Uexküll's Theoretische Biologie (1928), Umwelt und Innenwelt der Tiere (1921) and Streifzüge (1934). Nevertheless, even the adult still has access to earlier processes of formation.

To keep the dynamics of the binding processes in mind, Uexküll had used symphonic terms, while Werner explored the organic formation of micromelodies in his related series of studies (Das 
Problem der motorischen Gestaltung, 1924; Über Mikromelodik und Mikroharmonik, 1925; Über die Ausprägung von Tongestalten, 1926). And like Uexküll, Werner addressed the bipolar functional dynamics of the signal and ten related action by biological examples. While Werner also quotes Buytendijk (Werner 1948: 59. 63), Uexküll has the equivalent observations from Fabre to illustrate his "psychoidal laws" (Uexküll, Kriszat 1934: 85, fig. 39; Uexküll 1930: 94, fig. 2), to point at the fact, that an acting organism will not realise the signal at its receptors border here in the ear or the eye, related to the internal world, but at a localisation of the moving and sounding source there outside in the environment. The same personal spatio-temporal dimensions were subject of the psychological research (Stern 1936; Muchow 1935).

\section{The preservation of pre-Nazi scientific tradition}

In 1919 the term Umwelt first was used by Werner (Werner 1919: 217). The first edition of his Einführung in die Entwicklungspsychologie in 1926 in book 2 follows the bipolar concept of the Aussenwelt and the Innenwelt with its specific physiognomic perception (Werner 1926: 45). His second edition in 1933 has the final distinction of the things-ofaction and the signal-things. To continue, it is interesting to realise, where Werner refers to Uexküll in his Comparative Psychology of Mental Development when he addresses his American audience. Though there are differences in the 2nd (1948) American edition and the 4th (1958) German edition (which incorporates the 1948 addenda), this German edition had a specific purpose: to preserve the pre-Nazi scientific tradition. But the three books of the American edition reveal much better the organic approach. Book 2 ("Primitive mental activities"2) is combining human psychology and animal psychology in its bifocal interest in the inner world of internal signal processing, while the outer world of action and personality is discussed in book 3 ("The world and personality"). This bifocal layout mirrors the functional circle in environmental access.

Clearly Werner even in the structure of his book presents the twofold organic model of the internal Merkwelt and the external Wirkwelt.

\footnotetext{
2 Book 2 includes five parts: I Sensori-motor, perceptual and affective organization; II Primitive imagery; III Primitive notions of space and time; IV Primitive action; V Primitive thought processes.
} 
Accordingly, Werner twice refers to Uexküll (Werner 1948: 61 [Book 2], and 379, 382 [Book 3]) to address the animal's environment, and to Martha Muchow to address the human personalistic environment by her mainly unpublished research (Werner 1948: 19, 72, 122, 227, 385), the research Werner himself tried to continue (Werner 1948: 122).

\section{The children's worlds}

In an article published in Character and Personality Werner has an elaborated view the personalistic approach, which also throws some light on the focus the Hamburg Psychological Institute once had:

The notion of a personal world provided the basis for the Hamburg Institute's program of investigation of the different types of such personal worlds. [...] But in the actual procedure of analysis not only the developmental stage, but the whole cultural setting as well must be taken in account. Hence, Martha Muchow's program for such an analysis seeks to establish a typology of the child-world and the adolescent-world, one that is definitely cognizant of specific cultural patterns in space and time. Miss Muchow, in strict conformity with this program, has made a study of the life-space of the city world. In this study she demonstrated for the first time the typical characteristics of the world of the child as thus conditioned. In her posthumous, most admirably written book, she has shown how life-space emerges from the interaction of external, nonpersonal factors and the child-like dispositions, how the child selects and interprets the outer stimuli, and molds them into a world of his own that is typically at different developmental stages.

These novel and productive approaches to the problems of childpsychology were tragically interrupted by M. Muchow's premature death [1933]. She was undoubtedly Stern's most brilliant pupil. Her studies realize the synthesis of personalistic theory and empiric investigation in perhaps its most fruitful form. (Werner 1938: 124)

While this exploration of the children's life-space as their actionworld, illustrated by the Muchow experiments in mental activity (Werner 1948: 72-75) had much to do with the studies in the territories of the dog at this time, the words "things-of-action" and "signal-quality" (Werner 1948: 61), the later action related chapters on "primitive worlds" (Werner 1948: 379) refer again to a paper written by Sarris on common aspects in the environment of the blind man and his guiding dog (Sarris 1931), there to introduce Martha Muchow's study of the environment of children in opposition to the world of the adult and the building bureaucracy (Werner 1948: 384-385). To illustrate the differences in the child's world of action compared to the 
view of the adult, Werner there also published some drawings. This brought ideas to the American public, which years later were renewed by Kevin Lynch in his The Image of the City (Lynch 1960), who then mentioned the metal worlds of Marcel Proust and Mark Twain, but apparently had no knowledge of the personalistic approach to the organic worlds, represented by the two mentioned chapters on personal worlds at both ends of the book Comparative Psychology.

\section{The Artist's worlds}

The children's worlds Werner linked with the artist's worlds. Already in 1913 Werner had published an article on melody driven symbol formation in poetry (Werner 1913: 432):

Klanglos schläft der Sommergarten.

Durch die Nacht, erschöpfte Tiere

Schleppen sich die großen Wolken

In die neuen Rastquartiere.

Quoting a poem of Detlef von Liliencron (1844-1909), he discussed emotional symbol formation, reflecting the operational world, in contrast to emotional driven symbol formation, reflecting the inner world. Later in this Hamburg personalistic respect, as mentioned, he quoted Baudelaire (Werner 1958: 56). Perhaps also this personalistic view has to be taken in account, reading Uexküll's Niegeschaute Welten (1936). There in chapter xiv, Uexküll describes his friendship with the poet Rilke:

'Was ist wirklich schön?' Es war eine Autorität, an die sie die Frage richtete, denn der Befragte war niemand Geringeres als der Dichter Rainer Maria Rilke. 'Die Schönheit gleicht einem Schmetterling, der gewisse Dinge bevorzugt, auf die setzt er sich, und sie werden schön', war die Antwort des Dichters. [...] '... Stil ist ein Maß, das wir an die Dinge herantragen und, wenn wir Dichter sind, in sie hineintragen, um sie zu formen, und das tun Sie, lieber Meister, in erster Linie.' 'Dann wäre ich selbst der Schmetterling', lächelte Rilke. (Uexküll 1936: 257, 258)

Accordingly, the last entry of Oskar Schlemmer, the painter and master at the Bauhaus, in his diary in 1.4.1943 quotes from a published letter of Rilke to Uexküll: "Die Kunst nicht für eine Auswahl aus der Welt halten, sondern für die restlose Verwandlung ins Herrliche hinein". In Heinz Werners Comparative Psychology of 
Mental Development children and artists become these butterflies, generating their specific worlds, to which still the distant (sachlich) man has access to.

The art-related research of Hamburg Philosophical and Psychological Institutes Werner tried to preserve, because only some of the pre-Nazi experiments could be published (Werner 1948, 70; Krauss 1930). Emphasising remarks of the painter Wassily Kandinsky (Werner 1926: 47; 1948: 71), Werner manifests his touch with the formation of modern art, which, as declared in the German edition, based on discoveries by the music-teacher and vocalist Gertrud Grunow (1870-1944) (Werner 1926: 68; 1958: 28, 66, 68, 72), who, like Kandinsky, earlier had been a master at the Bauhaus (entry in the 1921 Weimar directory). Later both lived in Berlin, but so far just a postcard by Gertrud Grunow, mentioning a Berlin meeting with Kandinsky in 1932, proves subsequent contact in the field of primary symbol formation. There are some further traces of research in primary colour form abstraction in the collaborate Hamburg animal psychology (Uexküll 1932: 432), and in research continued by Martin Scheerer, who also had left Germany to Columbia University (Goldstein, Scheerer 1941). Some further hints again are found in Werner's Comparative Psychology (Werner 1948: 235).

Werner throughout there refers to facts which otherwise are associated with the productive pedagogical training at the Weimar Bauhaus (Werner 1958: 46, 81, 92, 162, 175). This relies to the personally bound functional circle of the productive artist to generate his objects and worlds. This training had to guide intuition. This organic approach is the common aspect in the original Weimar writings published in 1923. But this common aspect is not an obscure common sense in European cultural dynamics, but a specific concept (Uexküll 1973: 49), which then was targeted by those, who still believed in the existence of an absolute objective world. Gertrud Grunow is known to have handed copies of the articles published by Uexküll in the Deutsche Rundschau to her Weimar students.

An article by Werner on rhythm (Werner 1919) clearly unveils, that his later research together with Gertrud Grunow touched her field as a profound teacher of rhythmical education by exactly the facts Uexküll had described as motor melodies. While a kind of autobiographic article: "Was ist Jaques-Dalcroze dem Sänger?", printed in the Rheinische-Musik und Theaterzeitung in 1911, presents herself as a follower of rhythmical education, in 1919 Werner in his "Rhythmik, eine mehrwertige Gestaltenverkettung” distinguishes rhythmical poly- 
figurations and a-rhythmical monofigurations. In this view objects as well as melodies (Tongestalten) are understood as arhythmic monofigurations: "Die Dinge der Umwelt sind einwertige, eindeutige Figurationen" (Werner 1919: 217). These monofigurations, like columns or steps, are the elements to compose motor related rhythmic environments; the related research in the environmental effects on motor activity was continued later by Paul von Schiller (Schiller 1934). The there mentioned artificial environment is known as architecture. Architecture in this view is a polyfiguration, like the compositon of a dance, a picture, a concert. This in mind, it is interesting to trace the figurative aspects even in the writings of the architect Walter Gropius. So far and without knowledge of Werner's publications, it was only the Italian art historian Carlo Guilio Argan, to understand her central position in the Weimar circle to train individually constructive motor activity (Argan 1962: 22).

While Stern had the term "Synkinesie" (Stern 1950: 218) to address her methods to train environmental access, the audience today unfortunately is confronted with the limitations of the English edition of Hans M. Winglers The Bauhaus (1969), which does not contain a full translation of the main writing of Gropius, "Idee und Aufbau des Staatlichen Bauhauses", but just parts of an early 1922 version of the Gropius text in translation, without reference to the printed full version of 1923. And just one the related illustrations of the volume Staatliches Bauhaus 1919-1923 was reproduced by Wingler, perhaps by copyright reasons: The full translation with all illustrations already had been published by the Museum of Modern Art (Bayer et al. 1938: 21 ), but published there without the related texts by Grunow and Kandinsky. Furthermore, Wingler did not print the layout of the 1923 exhibition, when a sequence of rooms presented the educational work of Grunow, Kandinsky and Klee together to the public. Consequently, all the references linking the Gropius text with the article written by Gertrud Grunow ("The creation of Living Form through Color, Form, and Sound") are lost.

Gertrud Grunow and Walter Gropius were both in contact with scientific research. Together with Gropius she had visited the first Berlin conference of the Association in Aesthetic and Art Research in 1913, and since early 1920 to 1924 she and her Weimar assistant Hildegard Heitmeyer (with a Hellerau diploma in rhythmical education) were the only professionals in art education at Weimar. Their training there was called "Harmonisierungslehre", to show their 
aim to enforce the environment directed productive interrelation of signal-things and things-of-action.

There was a common sense in the Weimar education referring to the productive dynamics in physical signal and physical action qualities: "Das bildnerische Werk entstand aus der Bewegung, ist selber festgelegte Bewegung und wird aufgenommen in der Bewegung (Augenmuskeln)", accordingly explained Klee in his "Schöpferische Konfession" (printed in 1920). These related writings by Kandinsky and Klee still are available and in print, while there are just rare traces on Grunows homogeneous methods, as Werner classified them. There remain some articles printed in the Journal Kunst und Jugend 1935 to 1938 about her preliminary education in sensation and expression. For this she used a spatial circle on the ground. This circle of about $2 \mathrm{~m}$ in diameter had twelve clock-face like locations, to place a tone or a colour on these places. The training of the interdependency of tone and colour then used the external location to feed back sensation in the internal world. Beyond this Froebel- or Montessorilike education in sensation and expression, her main interest was symbol and artefact formation by motor activity. At Clark University, Worchester, the Werner papers give no further hint on this Innenweltdriven Aussenwelt formation in perception and creation. And the manuscript of her final summarizing work definitely is destroyed. Few is known of the content of her the volumes, which apparently intended to fit the three volumes of the Philosophy of Symbolic Forms of Cassirer, which he had presented her when he left Hamburg in 1933, while she moved in contact with Gertrud Bing and the Warburg Institute to London. But Bing later destroyed all her letters even in the London Institute, and no traces remained there about the "Pathosformel" related motor formation, which was another aspect of higher order symbol formation.

Uexküll in his "Theoretical biology" has a chapter "Das Schauen" (Uexküll 1973: 46) where he exactly addresses the biological view of tone and colour, Grunow already discussed in her 1923 article "Der Aufbau der lebendigen Form durch Farbe, Form, Ton" — with reference to the biological view. The same view is found also in the contribution of Walter Gropius: "Idee und Aufbau des Staatlichen Bauhauses". Even this title pronounced the bipolar environment paradigm: "Nichts besteht mehr an sich, jedes Gebilde wird zum Gleichnis eines Gedankens, der aus uns zur Gestaltung drängt ... " In fact, this personal bipolarity is the basis of the concept to handle the personal unification in environment directed motor activity. The secret 
of the world is not behind the object, but behind the subject, as Uexküll proposed in his theoretical biology, to ask "denn warum sollten zwei räumliche Eindrücke im gleichen Subjekt sich nicht beeinflussen?" (Uexküll 1973: 50). Consequently there was a training to perceive and handle the primary classes of matter and shape, to shape the "Werkwelt", at term associated with the term "Wirkwelt", while the formative dynamics of the personal world occur as "bewegter lebendiger künstlerischer Raum" (Gropius 1923: 9).

Though the contact of Gropius to the publications of Uexküll nowhere seem to be realized, he had provable knowledge since 1919, when in a letter dated Weimar, December 29, he wrote to Adolf Behne, that for the Bauhaus students he, Gropius, had bought 30 prints of his "Wiederkehr der Kunst" (Leipzig 1919). There p. 109 Behne summarised the view of Uexküll (Bausteine einer biologischen Weltanschauung, 1913) and referred to his own article "Biologie und Kubismus" (1917/1918: 694-705).

\section{Conclusion}

"Unsere Empfindungen und Vorstellungen sind Zeichen, nicht Abbilder der Gegenstände" Cassirer concluded in his "Substanzbegriff und Funktionsbegriff" in 1910. The Hamburg scientists Cassirer, Stern, Uexküll and Werner in the pre-Nazi time renewed the idea of the "empirical scheme of the objects", which at their time synchronized European philosophy with American Philosophy, emphasising their relation with ideas pronounced by William James (Teuber 1982). The "stream of consciousness" in the organic view of personalistics receives a new biological platform (Cassirer 1994: 210; Stern 1950: 715). While there is a formative interrelation of Henry and William James, the formative interrelation of the Hamburg scientist's organic view is leading to the Weimar Bauhaus. This contact to the artists of their time was mirrored by their life and work. In touch with this productive world of signs, cooperating with Gertrud Grunow and Wassily Kandinsky, Werner is said to have lived with his wife, the dancer Jo Gervai, in Hamburg in a Bauhaus environment (Marianne Teuber). And Fritz Heider, who had left Stern's Hamburg Institute before 1933, focused aspects of this Hamburg view in his description of the psychological environment in the world of Proust (Heider 1941). While the Hamburg institutes had focused formative dynamic 
motor aspects in the bipolarity of the internal and external worlds until 1933, looking at equivalent signals and intermodal aspects in animal, child and adult psychology, a more psycho-physical approach to measure the facts in environmental access followed G. A. Brecher (Brecher 1932) and E. v. Skramlik (Skramlik 1937), when Viktor v. Weizsäcker developed a new personal concept (Gestaltkreis) of psychophysical dynamics in environmental interrelation (Weizsäcker 1939), while J. H. Schultz, with his "autogenic training", allowed the mental access of internal thresholds, mentioning Uexküll's early articles on sea urchins (Schultz 1950: 33).

\section{References}

Argan, Giulio Carlo 1962. Gropius und das Bauhaus. Reinbeck bei Hamburg: Rowolt.

Auersperg, Alfred Prinz 1937. Landschaft und Gegenstand in der optischen Wahrnehmung, Archiv für die gesamte Psychologie 99: 129-141.

Bayer, Herbert; Gropius, Walter; Gropius, Ise (eds.) 1938. Bauhaus: 1919-1928. New York: The Museum of Modern Art.

Behne, Adolf 1917/1918. Biologie und Kubismus. Die Tat 9: 694-705.

- 1919. Wiederkehr der Kunst. Leipzig: Wolff.

Brecher, Gerhard A. 1932. Die Entstehung und biologische Bedeutung der subjektiven Zeiteinheit, - des Moments. Zeitschrift für vergleichende Physiologie 18: 204-243.

Cassirer, Ernst 1910. Substanzbegriff und Funktionsbegriff: Untersuchungen über die Grundfragen der Erkenntniskritik. Berlin.

- 1990 [1929]. Philosophie der Symbolischen Formen III: Phänomenologie der Erkenntnis. 9th ed. Darmstadt.

- 1994. Das Erkenntnisproblem in der Philosophie und Wissenschaft der neueren Zeit, vol. 1-4 (1906-1957), Darmstadt.

Dürckheim, Karlfried Graf von 1932. Über Gundformen des Raumerlebens. In: Kafka, Gustav (ed.), Bericht über den 12. Kongreß der Deutschen Gesellschaft für Psychologie in Hamburg (vom 12.-16. April 1931). Jena: G. Fischer, 318-320.

- 1934. Grundformen gelebter Zeit. In: Klemm, Otto (ed.), Bericht über den 13. Kongreß der Deutschen Gesellschaft für Psychologie in Leipzig, 1933. Jena: G. Fischer, 129-131.

Goldstein, Kurt; Scheerer, Martin 1941. Abstract and concrete behaviour: An experimental study with special tests. Psychological Monographs 53(2): 1151.

Gropius, Walter; et al. 1923. Staatliches Bauhaus Weimar 1919-1923. Weimar and Munich: Bauhausverlag.

Gutberlet, Constantin 1907. Die Substanz als Bewegungsmelodie. Philosophisches Jahrbuch 20: 426-441. 
Heider, Fritz 1939. Environmental determinants in psychological theories. The Psychological Review 46: 383-410.

- 1941. Description of the psychological environment in the work of Marcel Proust. Character and Personality 9.

Kant, Immanuel 1911 [1787]. Kritik der reinen Vernunft, 2nd ed., $1787=$ Kant's gesammelte Schriften I, vol. 3, Berlin 1911 (ed. Königl. Preußische Akademie der Wissenschaften).

Klee, Paul 1920. Schöpferische Konfession. Tribüne der Kunst und Zeit 13: 2840.

Krauss, R. 1930. Über graphischen Ausdruck. Zeitschrift für angewandte Psychologie 48: 1-141.

Krueger, Felix 1915. Über Entwicklungspsychologie. Leipzig: W. Engelmann.

Lynch, Kevin 1960. The Image of the City. Cambridge: MIT Press.

Meumann, Ernst 1919. Ästhetik der Gegenwart. 3rd ed. Leipzig.

Muchow, Martha; Muchow, Hans Heinrich 1935. Der Lebensraum des Großstadtkindes. Hamburg: Martin Riegel.

Sarris, Emanuel Georg 1931. Sind wir berechtigt vom Wortverständnis des Hundes zu sprechen? Zeitschrift für Angewandte Psychologie, Beiheft 62.

Schiller, Paul von 1934. Wirkung des Umfeldes auf motorische Leistungen. Zeitschrift für Psychologie 132: 83-103.

Schulz, Johannes Heinrich 1950 [1930]. Das autogene Training. 6th ed. Stuttgart: G. Thieme.

Skramlik, Emil von 1937. Psychophysiologie der Tastsinne. (= Archiv für die gesamte Psychologie, Erg. Bd. 4). Leipzig: Akademische Verlagsgesellschaft.

Stern, William 1894. Die Wahrnehmung von Bewegungen vermittelst des Auges. Zeitschrift für Psychologie und Physiologie der Sinnesorgane 7: 321-386. (Also as offprint: Hamburg and Leipzig: Leopold Voss 1894, 68 p.)

- 1931. Das Psychologische Institut der Hamburgischen Universität in seiner gegenwärtigen Gestalt. Dargestellt aus Anlaß des XII. Kongresses der Deutschen Gesellschaft für Psychologie in Hamburg 12. bis 16. April 1931. Leipzig: Barth.

- 1933. Raum und Zeit als personale Dimensionen. Forschungen und Fortschritte 9(2): 20-21.

- 1936. Raum und Zeit als personale Dimensionen. Acta Psychologica 1: 220232.

- 1950 [1935]. Allgemeine Psychologie auf personalistischer Grundlage. 2nd ed. Haag: M. Nijhoff.

Teuber, Marianne L. 1982. Formvorstellung und Kubismus oder Pablo Picasso und William James. In: Gohr, Siegfried (ed.), Kubismus, Künstler, Themen, Werke 1907-1920. Köln: Josef-Haubrich-Kunsthalle, 9-57.

Uexküll, Gudrun von 1964. Jakob von Uexküll: Seine Welt und seine Umwelt. Hamburg: C. Wegner.

Uexküll, Jakob von 1907. Die Umrisse einer kommenden Weltanschauung. Die neue Rundschau 18(6): 641-661.

- 1913. Bausteine zu einer biologischen Weltanschauung: Gesammelte Aufsätze. München: F. Bruckmann.

- 1920. Theoretische Biologie. Berlin: Paetel.

- 1930. Die Lebenslehre. Potsdam: Müller und Kiepenheuer. 
- 1932. Das Duftfeld des Hundes. In: Kafka, Gustav (ed.), Bericht über den 12. Kongreß der Deutschen Gesellschaft für Psychologie in Hamburg (vom 12.16. April 1931). Jena: G. Fischer, 431-435.

- 1936. Niegeschaute Welten. Die Umwelten meiner Freunde. Ein Erinnerungsbuch. Berlin: S. Fischer.

- 1973 [1920, 1928]. Theoretische Biologie. 3rd ed. Frankfurt am Main: Suhrkamp.

Uexküll, Jakob von; Kriszat, Georg 1934. Streifzüge durch die Umwelten von Tieren und Menschen. Berlin: J. Springer.

Weizsäcker, Viktor von 1943 [1939]. Der Gestaltkreis: Theorie der Einheit von Wahrnehmen und Bewegen. 2nd ed. Heidelberg: Thieme.

Werner, Heinz 1913. Über die künstlerisch-individuellen Prozesse. Archiv für Systematische Philosophie 19: 429-441.

- 1919. Rhythmik, einer mehrwertige Gestaltenverkettung. Zeitschrift für Psychologie 82: 198-218.

- 1922. Grundfragen der Intensitätspsychologie. (Zeitschrift für Psychologie, Ergzbd.) Leipzig.

- 1924. Das Problem der motorischen Gestaltung (= Studien über Strukturgesetze II). Zeitschrift für Psychologie 94: 265-272.

- 1925. Über Mikromelodik und Mikroharmonik (= Studien über Strukturgesetze IV). Zeitschrift für Psychologie 98: 74-89.

- 1926. Über die Ausprägung von Tongestalten (= Studien über Strukturgesetze V). Zeitschrift für Psychologie 101: 159-181.

- 1926. Einführung in die Entwicklungspsychologie. Leipzig: Barth.

- 1932. Über das 'Empfinden' und seine experimentelle Prüfung, In: Kafka, Gustav (ed.), Bericht über den 12. Kongreß der Deutschen Gesellschaft für Psychologie in Hamburg (vom 12.-16. April 1931). Jena: G. Fischer, 190-191.

- 1933. Einführung in die Entwicklungspsychologie. 2nd ed. Leipzig: Barth.

- 1938. William Stern's personalistics and psychology of personality. Character and Personality 7: 108-125.

- 1945. Motion and motion perception: a study on vicarious functioning. The Journal of Psychology 19: 317-327.

- 1948 [1940]. Comparative Psychology of Mental Development. 2nd ed. Chicago: Follett.

- 1958 [1926]. Einführung in die Entwicklungspsychologie. 4th ed. München: Barth.

Werner, Heinz; Kaplan, Bernard 1963. Symbol Formation: An OrganismicDevelopmental Approach to Language and the Expression of Thought. New York: Wiley.

Wingler, Hans M. 1969. The Bauhaus. Cambridge: MIT Press.

Wohlwill, Hedwig Elisabeth 1933. Typische Verhaltensweisen im Wahrnehmen. eine experimentelle Untersuchung. Hamburg: Dissertation der Hamburgischen Universität. 


\section{Формирование символа}

Понятие формирование символа объединяет повлиявшие друг на друга исследовательские работы в Гамбургском университете до 1933 года: в Институте философии (Вильям Штерн, Эрнст Кассиpep), в Институте психологии (Штерн) и в его лаборатории (Хайнц Вернер) и в Институте Umwelt'a (Якоб фон Юкскюлл). Это понятие, в том смысле, как его использовали Кассирер и Вернер, связано с персоналистским подходом (Штерн), но охватывает и близкие термины как 'мелодия движения' (Юкскюлл) и 'реляционное содержание' (Кассирер), развивая понятие 'эмпирической схемы' (Кант). Одновременно все они связаны с проблемой структурирования порога при равных стимулах. Этот взгляд интермодального формирования позволяет исследовать общие стороны в Umwelt'ax животных, детей и взрослых и производство символа у художников (Weimar Bauhaus) и поэтов (Р. М. Рильке).

\section{Sümboliloome}

Sümboliloome on mõiste, mille kaudu ühenduvad vastastikku teineteist mõjustanud uurimistööd Hamburgi ülikoolis enne 1933. aastat: Filosoofia Instituudis (William Stern, Ernst Cassirer), Psühholoogia Instituudis (Stern) ja selle Laboratooriumis (Heinz Werner), ning Keskkonna Instituudis (Jakob von Uexküll). See mõiste, nagu teda kasutasid Cassirer ja Werner, seondub personalistliku lähenemisega (Stern), kuid haarab ka seotud termineid nagu 'liikumise meloodia' (Uexküll) ja 'relatsiooniline sisu' (Cassirer), arendades 'empiirilise skeemi' (Kant) mõistet. Ühtaegu on kõik need seotud läve struktureerimise probleemiga võrdsete stiimulite puhul. Intermodaalne arusaam võimaldas uurida ühiseid tahke loomade, laste ja täiskasvanute omailmas ning sümboliloomet kunstnikel (Weimar Bauhaus) ja luuletajail (R. M. Rilke). 